\title{
Effects of Glucagon-Like Peptide-1 Receptor Agonists on $\beta$-Cell Function in Patients with Type 2 Diabetes
}

Susan Grandy*, Alka Shaunik and Elise Hardy

AstraZeneca, Gaithersburg, Maryland, USA

\begin{abstract}
Type 2 diabetes (T2D) is characterized by insulin resistance and a progressive decline in pancreatic $\beta$-cell function. Over time, upregulation of insulin secretion is no longer sufficient to compensate for insulin resistance, leading to fasting hyperglycemia, while $\beta$-cell function continues to deteriorate. Effective treatments targeting the underlying pathophysiology of T2D involve early lifestyle interventions and a combination of therapies to counteract insulin resistance and progressive deterioration of $\beta$ cells. Glucagon-like peptide-1 receptor agonists (GLP-1RAs) are one class of antihyperglycemic agents that target multiple pathways, mediating clinical benefits for patients with T2D. This review summarizes the effects of treatment with various GLP-1RAs, including exenatide (twice daily and once weekly), liraglutide, dulaglutide, and lixisenatide, on $\beta$-cell function in patients with T2D. $\beta$-cell function was assessed in randomized controlled trials and their extension studies using a variety of methods, including glucose and arginine clamp techniques, proinsulin-to-insulin ratio, and homeostatic model assessment of $\beta$-cell function (HOMA-B). Exenatide twice daily and liraglutide both improved first- and second-phase insulin secretory responses. In addition, numerous studies reported significant improvements in HOMA-B with exenatide (twice daily and once weekly; range of relative change from baseline: $+28-50 \%$; range of absolute change: $+5-40 \%$ ) or liraglutide (range of change vs. placebo: $+13-43 \%)$. Improvements in HOMA-B were also observed with the newer GLP-1RAs dulaglutide and lixisenatide. In contrast to the effects on HOMA-B, treatment with GLP-1RAs had a lesser effect on insulin sensitivity. Taken together, the results suggest that glucagon-like peptide-1 analogs have a greater effect on $\beta$-cell function than insulin sensitivity.
\end{abstract}

Keywords: $\beta$-cell function; Exenatide; Glucagon-like peptide-1 receptor agonist; Type 2 diabetes

\section{Introduction}

Type 2 diabetes (T2D) is a chronic, complex illness characterized by insulin resistance and a progressive failure of $\beta$-cell function $[1,2]$. The natural history of T2D involves early development of postprandial hyperglycemia followed by the development of fasting hyperglycemia. Over time, upregulated insulin secretion is no longer able to compensate for increased insulin resistance, and there is continued deterioration of residual $\beta$ cells. The pathophysiology of T2D involves deficiencies in insulin, amylin, and incretins. At diagnosis, over $80 \%$ of the $\beta$-cell response to glucose appears lost [1], and the loss of the first-phase insulin response is recognized as an early $\beta$-cell defect in T2D [3]. A multihormonal model of glucose homeostasis beyond the established anabolic and catabolic roles of insulin and glucagon, respectively, is well recognized (Table 1); additional hormones including amylin and glucagon-like peptide-1 (GLP-1) have been identified as crucial components of glucose regulation (Figure 1) [4]. GLP-1, an incretin hormone synthesized in intestinal $\mathrm{L}$ cells and released in response to nutrient ingestion, plays a key role in priming the $\beta$ cell to respond to plasma glucose. Indeed, the "incretin effect" (i.e. augmented insulin secretion in response to glucose ingested in a meal vs. glucose infused intravenously) has been estimated to account for up to $70 \%$ of the $\beta$-cell response at mealtime [5].

Insulin responses to physiological levels of GLP-1 are severely impaired in T2D but are restored by pharmacological doses of GLP-1. Højberg and colleagues, while investigating the potentiation of glucosestimulated insulin secretion by GLP-1, identified that physiological levels of GLP-1 resulted in an increase in insulin secretion in healthy subjects. However, in patients with $\mathrm{T} 2 \mathrm{D}$, the insulin response to physiological levels of GLP-1 was substantially reduced [6]. Vilsbøll et al. investigated GLP-1 stimulation in patients with T2D and found that
GLP-1 infused at pharmacological levels ( $1 \mathrm{pmol} / \mathrm{kg} / \mathrm{min})$ augmented late-phase insulin secretion to levels similar to those observed in healthy subjects [7].

GLP-1 receptor agonists (GLP-1RAs) are one class of antihyperglycemic agents that target multiple pathways, mediating clinical benefits for patients with T2D. GLP-1RAs have been shown to reduce $\mathrm{HbAlc}$, fasting and postprandial plasma glucose, and body weight, and are associated with a low risk of hypoglycemia when not taken with other drugs associated with hypoglycemia such as sulfonylureas [8]. A number of GLP-1RAs are currently available, including exenatide twice daily or once weekly, liraglutide once daily, lixisenatide once daily, albiglutide once weekly, and dulaglutide once weekly, which are administered via subcutaneous (SC) injection and indicated as an adjunct to diet and exercise to improve glycemic control in adults with T2D.

GLP-1RAs lower glucose through a multifaceted mechanism of action, as these agents mimic the myriad actions of endogenous GLP1 [9-13]. Activation of downstream signaling pathways initiated by GLP-1RAs stimulates first- and second-phase postprandial glucosedependent insulin secretion and suppresses inappropriately elevated

*Corresponding author: Susan Grandy, Global Medicines Development AstraZeneca, One Medlmmune Way, Gaithersburg, MD 20878, USA, Tel: 301-3980543; E-mail: susan.grandy@astrazeneca.com

Received January 08, 2016; Accepted January 23, 2016; Published January 30 2016

Citation: Grandy S, Shaunik A, Hardy E (2016) Effects of Glucagon-Like Peptide-1 Receptor Agonists on $\beta$-Cell Function in Patients with Type 2 Diabetes. J Diabetes Metab 7: 643. doi:10.4172/2155-6156.1000643

Copyright: $\odot 2016$ Grandy S, et al. This is an open-access article distributed unde the terms of the Creative Commons Attribution License, which permits unrestricted use, distribution, and reproduction in any medium, provided the original author and source are credited. 


\begin{tabular}{|c|c|}
\hline Pancreas & \\
\hline$\alpha$ cells & \\
\hline Glucagon & $\begin{array}{l}\text { - Stimulates the breakdown of stored liver glycogen } \\
\text { - Promotes hepatic gluconeogenesis } \\
\text { - Promotes hepatic ketogenesis }\end{array}$ \\
\hline$\beta$ cells & \\
\hline Insulin & $\begin{array}{l}\text { - Affects glucose metabolism and storage of ingested nutrients } \\
\text { - Promotes glucose uptake by cells } \\
\text { - Suppresses postprandial glucagon secretion } \\
\text { - Promotes protein and fat synthesis } \\
\text { - Promotes use of glucose as an energy source }\end{array}$ \\
\hline Amylin & $\begin{array}{l}\text { - Suppresses postprandial glucagon secretion } \\
\text { - Slows gastric emptying } \\
\text { - Reduces food intake and body weight }\end{array}$ \\
\hline Intestine & \\
\hline L cells & \\
\hline GLP-1 & $\begin{array}{l}\text { - Enhances glucose-dependent insulin secretion } \\
\text { - Suppresses postprandial glucagon secretion } \\
\text { - Slows gastric emptying } \\
\text { - Reduces food intake and body weight } \\
\text { - Promotes } \beta \text {-cell health }\end{array}$ \\
\hline $\begin{array}{l}\text { GLP-1: glu } \\
\text { Reproduce }\end{array}$ & $\begin{array}{l}\text { gon-like peptide-1. } \\
\text { from Aronoff SL [4] }\end{array}$ \\
\hline
\end{tabular}

Table 1: Effects of primary glucoregulatory hormones.

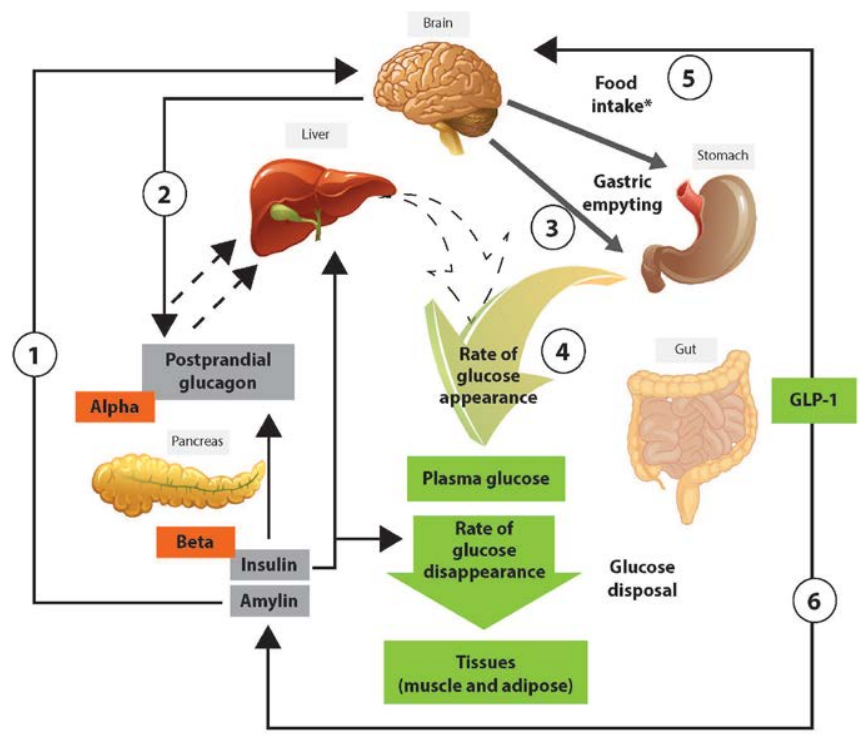

Figure 1: Glucose homeostasis: roles of insulin, glucagon, amylin, and GLP-1. The multi-hormonal model of glucose homeostasis (nondiabetic individuals): in the fed state, amylin communicates through neural pathways (1) to suppress postprandial glucagon secretion (2) while helping to slow the rate of gastric emptying (3). These actions regulate the rate of glucose appearance in the circulation (4). *In animal models, amylin has been shown to dose-dependently reduce food intake and body weight (5). In addition, incretin hormones, such as GLP-1, glucose-dependently enhance insulin secretion (6) and suppress glucagon secretion (2) and, via neural pathways, help slow gastric emptying and reduce food intake and body weight (5). GLP1: glucagon-like peptide-1. Reproduced with permission from Aronoff SL [4].

glucagon secretion [14], which in turn reduces hepatic glucose production [15]. Furthermore, GLP-1RAs slow gastric emptying, decrease food intake, and promote satiety [14]. Because native GLP-1 and GLP-1RAs were shown to reduce apoptosis and/or increase cellular proliferation and $\beta$-cell mass in rodent models of diabetes and insulin resistance [16,17], it was hypothesized that GLP-1RAs may modify $\beta$-cell function in patients with T2D. Additionally, a GLP-1RA applied to muscle and adipocyte cell lines has been shown to augment insulin sensitivity in preclinical models [18]. In humans, GLP-1RA treatment increased insulin sensitivity (assessed using hyperinsulinemiceuglycemic clamp studies) in patients with type 1 diabetes [19].

Various methods for evaluating $\beta$-cell function are available, including glucose and arginine clamp techniques, the proinsulinto-insulin ratio, and mathematical equations describing glucose homeostasis such as the homeostatic model assessment of $\beta$-cell function (HOMA-B) [20]. HOMA-B is a surrogate measure of the ability of $\beta$ cells to secrete insulin-rather than a measure of $\beta$-cell health - and should be evaluated in light of insulin sensitivity, assessed using the homeostatic model assessment of insulin sensitivity or insulin resistance (HOMA-S or HOMA-IR, respectively) [21]. The proinsulinto-insulin ratio may be indicative of impaired $\beta$-cell secretory capacity, as deteriorating $\beta$ cells are deficient in processing proinsulin and secrete abnormally high levels of proinsulin relative to insulin [20].

This review examines the impact of GLP-1RAs on $\beta$-cell function in patients with T2D by summarizing published randomized controlled trials, extension studies, and post hoc analyses that evaluated $\beta$-cell function after treatment with various GLP-1RAs. A PubMed search was conducted using the terms "exenatide," "liraglutide," "dulaglutide," "albiglutide," or "lixisenatide" and " $\beta$-cell function" and "type 2 diabetes." Results were reviewed and selected individually.

\section{Exenatide}

Exenatide was the first GLP-1RA approved for the treatment of T2D and is available in a twice-daily $(5-10 \mu \mathrm{g}) \mathrm{SC}$ formulation and a once-weekly ( $2 \mathrm{mg}$ ) extended-release SC formulation. Encapsulation of the active molecule, exenatide, into biodegradable poly (D, L-lactideco-glycolide) microspheres enables the continuous release of exenatide from the once-weekly formulation [22].

\section{Effects of Intravenous Exenatide on $\beta$-Cell Function}

Fehse et al. investigated insulin secretory patterns and the effects of exenatide on insulin secretion and found that in patients with T2D $(\mathrm{N}=13)$, the first-phase insulin response was reduced compared with healthy control subjects $(\mathrm{N}=12)$ [23]. Intravenous infusion of exenatide for 300 minutes increased first-phase (0-10 minutes) and secondphase (defined in this study as 10-120 minutes) insulin secretion by approximately $180-310 \%$ (Figure 2 ). Thus, short-term exposure to exenatide restored the first-phase response, resulting in an insulin secretory pattern similar to that observed in healthy subjects.

\section{Effects of Exenatide Twice Daily on $\beta$-Cell Function}

\section{Functional studies}

DeFronzo et al. investigated $\beta$-cell function using hyperglycemic and euglycemic insulin clamp techniques among patients $(\mathrm{N}=50)$ on background metformin therapy randomized to receive exenatide twice daily, rosiglitazone, or combination therapy [24]. After 20 weeks, significant reductions from baseline in $\mathrm{HbAlc}$ were observed with all treatments $(\mathrm{p}<0.05)$. Exenatide twice daily or exenatide twice daily plus rosiglitazone significantly enhanced the first- and second-phase insulin secretory responses compared with baseline $(\mathrm{p}<0.05)$, whereas rosiglitazone alone had no significant effect on insulin secretion. In contrast, rosiglitazone was associated with a two-fold increase in insulin sensitivity, while exenatide twice daily had no significant insulin-sensitizing effect. $\beta$-cell function was further evaluated using the disposition index, which is calculated from hyperglycemic and 


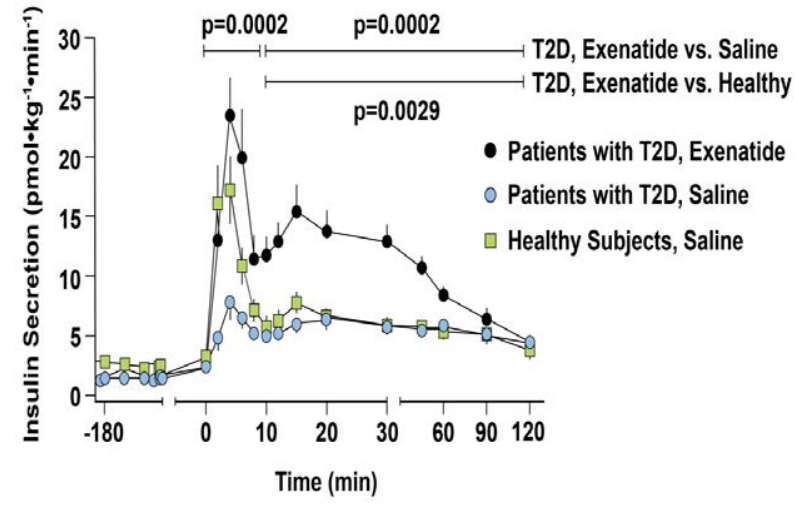

Figure 2: Insulin secretion rates in 13 patients with T2D given an intravenous infusion of exenatide (black circles) or saline (white circles) and 12 healthy subjects given an infusion of saline (white squares). Repeated-measures analysis of variance indicated significant differences in insulin secretion as measured by area under the concentration-time curve analysis of the first(0-10 minutes) and second-phase (10-120 minutes) insulin release between patients with $T 2 D$ treated with exenatide and saline. Exenatide-treated patients with T2D had significantly increased second-phase insulin release, compared with healthy subjects. Data represent the mean \pm standard error. T2D: type 2 diabetes. Reproduced with permission from Fehse F, et al. [23].

euglycemic insulin clamp measures and considered the gold standard of $\beta$-cell function. The disposition indices increased significantly from baseline after treatment with exenatide twice daily or combination therapy (both $\mathrm{p}<0.05$ ), but not with rosiglitazone alone. Therefore, exenatide twice daily in combination with rosiglitazone had favorable effects on both $\beta$-cell secretory function and insulin sensitivity.

In another study, $\beta$-cell function was assessed using glucoseand arginine-stimulated hyperglycemic clamp procedures among patients $(\mathrm{N}=69)$ randomly assigned to receive exenatide twice daily or insulin glargine for 52 weeks [25]. After 52 weeks, exenatide twice daily significantly increased all measures of $\beta$-cell function compared with insulin glargine. First-phase glucose-stimulated C-peptide secretion was significantly greater with exenatide twice daily versus insulin glargine (geometric mean \pm standard error ratio to baseline: $1.78 \pm 0.11$ vs. $1.17 \pm 0.06 ; \mathrm{p}<0.0001)$. Likewise, the second-phase response was enhanced with exenatide twice daily compared with insulin glargine $(3.05 \pm 0.22$ vs. $1.08 \pm 0.05 ; \mathrm{p}<0.0001)$. Exenatide twice daily significantly increased arginine-stimulated C-peptide secretion compared with insulin glargine $(3.19 \pm 0.24$ vs. $1.31 \pm 0.07$; $\mathrm{p}<0.0001)$. In both treatment groups, measures returned to baseline values following 4 weeks of study drug discontinuation. Thus, $\beta$-cell improvements reflected functional responses to exenatide exposure, rather than persistent $\beta$-cell modification. Thirty-six patients completed the 2-year extension study [26]. After 3 years of total exposure followed by a 4 -week discontinuation period, glucose- and arginine-stimulated responses returned to baseline measures among patients treated with exenatide twice daily or insulin glargine. The change from baseline in the disposition index demonstrated a small, sustained beneficial effect on $\beta$-cell function posttreatment with exenatide twice daily, whereas there was a reduction in the disposition index with insulin glargine $(1.43 \pm 0.78$ vs. $-0.99 \pm 0.65 ; p=0.028)$. Thus, there was a sustained improvement in the disposition index with exenatide twice daily, which was maintained 4 weeks after treatment discontinuation, whereas there was no significant effect of insulin glargine on this benchmark measure of $\beta$-cell function despite similar glycemic control. Glycemic control reverted to pretreatment levels in all patients, indicating improvements in $\beta$-cell function did not reverse glycemic dysfunction.

Recently, Xu et al. reported results from a randomized controlled trial directly comparing the effects of exenatide twice daily, premixed insulin, and pioglitazone on $\beta$-cell function in newly diagnosed, treatment-naïve patients with T2D $(\mathrm{N}=342)$ [27]. After 48 weeks, significant improvements in the proinsulin-to-insulin ratio, acute insulin response, and disposition index were observed across treatments, while only insulin significantly improved HOMA-B. Exenatide twice daily, insulin, and pioglitazone increased the acute insulin response from baseline by $42.4,30.4$, and $31.9 \mu \mathrm{IU} \mathrm{mL} \mathrm{min}^{-1} \times$ min respectively (exenatide twice daily and pioglitazone: $\mathrm{p}<0.001$; insulin: $\mathrm{p}<0.05$ ), and increased the disposition index from baseline by $1.3,0.5$, and 0.4 (all $\mathrm{p}<0.05)$. Thus, early intervention with glucose-lowering treatments improved multiple measures of $\beta$-cell function with continued treatment.

\section{HOMA-B}

Changes in HOMA-B after treatment with exenatide twice daily in various clinical studies are summarized in (Table 2). In order to provide a meaningful interpretation of $\beta$-cell function, it is important to evaluate function within the context of insulin resistance, which precedes $\beta$-cell deterioration and is compensated for by increased insulin secretion [28]. Thus, when assessing $\beta$-cell function using HOMA measures, it is important to also evaluate insulin resistance (measured using HOMAIR) or the inverse, insulin sensitivity (HOMA-S). In general, exenatide twice daily had little or no effect on insulin sensitivity; however, few data exist reporting HOMA-B measures in conjunction with HOMA-S or HOMA-IR measures.

Several studies have investigated the use of exenatide twice daily early in the course of disease progression. $\beta$-cell function was assessed using HOMA-B among treatment-naïve patients randomized to receive exenatide $5 \mu \mathrm{g}$, exenatide $10 \mu \mathrm{g}$, or placebo twice daily for 24 weeks [29]. HOMA-B increased from baseline by $32 \%$ and $28 \%$ in the exenatide $5 \mu \mathrm{g}$ and $10 \mu \mathrm{g}$ groups, respectively, versus $6 \%$ in the placebo group. Improvements were significantly greater with exenatide twice daily versus placebo (exenatide twice daily $5 \mu \mathrm{g}, \mathrm{p}=0.002$; exenatide twice daily $10 \mu \mathrm{g}, \mathrm{p}=0.010)$. Thus, the use of exenatide therapy early in the treatment paradigm substantially improved $\beta$-cell function. In obese Chinese patients newly diagnosed with $\mathrm{T} 2 \mathrm{D}$ and naïve to treatment for diabetes, HOMA-B increased slightly, but not significantly, after 26 weeks of treatment with exenatide twice daily or metformin (Table 2) [30]. In contrast, HOMA-S (reflecting insulin sensitivity) increased significantly with exenatide twice daily compared with metformin $(\mathrm{p}=0.042)$. Relatively high levels of initial $\beta$-cell function-most likely due to the short duration of diabetes ( $<1$ month) in these patients-may have accounted for the lack of significant improvement in HOMA-B. Nevertheless, exenatide twice daily preserved $\beta$-cell function over 26 weeks.

Changes in HOMA-B were assessed among 86 patients who received exenatide twice daily or oral sitagliptin for 4 weeks before crossing over to the other therapy for an additional 4 weeks [31]. Both treatments significantly improved HOMA-B, with a significantly greater change from baseline observed with exenatide twice daily versus sitagliptin $(+32.9 \pm 3.8 \%$ vs. $+20.8 \pm 3.9 \%$; $\mathrm{p}=0.005)$.

In a randomized, placebo-controlled trial $(\mathrm{N}=194)$ comparing 24 weeks' treatment with exenatide twice daily in combination with lifestyle modification versus lifestyle modification alone, HOMA-B improved significantly in both treatment groups [32]. HOMA-B 
Citation: Grandy S, Shaunik A, Hardy E (2016) Effects of Glucagon-Like Peptide-1 Receptor Agonists on $\beta$-Cell Function in Patients with Type 2 Diabetes. J Diabetes Metab 7: 643. doi:10.4172/2155-6156.1000643

Page 4 of 8

\begin{tabular}{|c|c|c|c|}
\hline Study & Design & $\beta$-Cell Function (HOMA-B) & Insulin Sensitivity (HOMA-S or HOMA-IR) \\
\hline \multicolumn{4}{|l|}{ Exenatide BID* } \\
\hline $\begin{array}{l}\text { Apovian CM, et al. } 2010 \\
\text { [32] }\end{array}$ & $\begin{array}{l}\text { 24-week parallel RCT, adjunct } \\
\text { to lifestyle modification and oral } \\
\text { agents }\end{array}$ & $\begin{array}{l}\text { Exenatide BID: Relative change from baseline, } \\
+42 \% \\
\text { Placebo: Relative change from baseline, }+23 \%\end{array}$ & Values not reported; NS \\
\hline $\begin{array}{l}\text { Berg JK, et al. } 2011 \\
\text { [31] }\end{array}$ & $\begin{array}{l}\text { Two-period, 4-week each, } \\
\text { crossover RCT, adjunct to oral } \\
\text { agents }\end{array}$ & $\begin{array}{l}\text { Exenatide BID: Mean } \pm \text { SE difference from } \\
\text { baseline, }+32.9 \pm 3.8 \% \\
\text { Sitagliptin: Mean } \pm \text { SE difference from baseline, } \\
+20.8 \pm 3.9 \%\end{array}$ & Not reported \\
\hline $\begin{array}{l}\text { Buse JB, et al. } 2007 \\
\text { [33] }\end{array}$ & $\begin{array}{l}\text { 2-year non-controlled extension of } \\
\text { three RCTs, adjunct to oral agents }\end{array}$ & $\begin{array}{l}\text { Exenatide BID: } \sim 45-50 \% \text { relative increase from } \\
\text { baseline }\end{array}$ & $\begin{array}{l}\text { Exenatide BID: }+8.3 \% \text { relative change from baseline } \\
\text { in median HOMA-S }\end{array}$ \\
\hline $\begin{array}{l}\text { Derosa G, et al. } 2010^{\dagger} \\
\text { [34] }\end{array}$ & $\begin{array}{l}\text { 1-year parallel RCT, adjunct to oral } \\
\text { agents }\end{array}$ & $\begin{array}{l}\text { Exenatide BID: Estimated difference, }+11.7 \\
\text { Glibenclamide: Estimated difference, }-1.5\end{array}$ & $\begin{array}{l}\text { Exenatide BID: Estimated difference in HOMA-IR, } \\
-3.0 \\
\text { Glibenclamide: Estimated difference in HOMA-IR, } \\
-0.5\end{array}$ \\
\hline $\begin{array}{l}\text { Derosa G, et al. } 2012 \\
\text { [35] }\end{array}$ & $\begin{array}{l}\text { 1-year parallel RCT, adjunct to oral } \\
\text { agents }\end{array}$ & $\begin{array}{l}\text { Exenatide BID: Treatment difference vs. placebo, } \\
+29 \%\end{array}$ & $\begin{array}{l}\text { Exenatide BID: HOMA-IR treatment difference vs. } \\
\text { placebo, }-1.1 \%\end{array}$ \\
\hline $\begin{array}{l}\text { Moretto TJ, et al. } 2008 \\
\text { [29] }\end{array}$ & 24-week parallel RCT, monotherapy & $\begin{array}{l}\text { Exenatide } 5 \mu \mathrm{g} \text { BID: Relative change from baseline, } \\
+32 \% \\
\text { Exenatide } 10 \mu \mathrm{g} \text { BID: Relative change from } \\
\text { baseline, }+28 \% \\
\text { Placebo: Relative change from baseline, }+6 \%\end{array}$ & Not reported \\
\hline $\begin{array}{l}\text { Preumont V, et al. } 2010 \\
\text { [36] }\end{array}$ & $\begin{array}{l}\text { 6-month, non-controlled, adjunct to } \\
\text { oral agents }\end{array}$ & $\begin{array}{l}\text { Exenatide BID: Mean } \pm \text { SD difference from baseline, } \\
+10 \pm 22 \%\end{array}$ & $\begin{array}{l}\text { Exenatide BID: Mean } \pm \text { SD difference from baseline in } \\
\text { HOMA-S, }+3 \pm 34 \%\end{array}$ \\
\hline $\begin{array}{l}\text { Yuan GH, et al. } 2012^{\ddagger} \\
\text { [30] }\end{array}$ & 26-week, parallel RCT, monotherapy & $\begin{array}{l}\text { Exenatide BID: Estimated difference, }+5.1 \\
\text { Metformin: Estimated difference, }+4.1\end{array}$ & $\begin{array}{l}\text { Exenatide BID: Estimated difference in HOMA-S, } \\
+15.8 \\
\text { Metformin: Estimated difference in HOMA-S, }+6.7\end{array}$ \\
\hline \multicolumn{4}{|l|}{ Exenatide QW } \\
\hline $\begin{array}{l}\text { MacConell L, et al. } \\
2013 \text { (DURATION-1 } \\
\text { extension) [38] }\end{array}$ & $\begin{array}{l}\text { 1-year open-label extension, } \\
\text { monotherapy or adjunct to oral } \\
\text { agents }\end{array}$ & $\begin{array}{l}\text { Exenatide QW: Mean } \pm \text { SE difference from } \\
\text { baseline, }+39.5 \pm 4.9 \%\end{array}$ & Not reported \\
\hline $\begin{array}{l}\text { MacConell L, et al. } \\
2013 \text { (DURATION-1 } \\
\text { extension) [38] }\end{array}$ & $\begin{array}{l}\text { 3-year open-label extension, } \\
\text { monotherapy or adjunct to oral } \\
\text { agents }\end{array}$ & $\begin{array}{l}\text { Exenatide QW: Mean } \pm \text { SE difference from } \\
\text { baseline, }+25.1 \% \pm 4.4 \%\end{array}$ & Not reported \\
\hline $\begin{array}{l}\text { Diamant M, et al. } 2010 \\
\text { (DURATION-3) [39] }\end{array}$ & $\begin{array}{l}\text { 26-week parallel RCT, adjunct to } \\
\text { oral agents }\end{array}$ & $\begin{array}{l}\text { Exenatide QW: Ratio to baseline, } 1.69 \\
\text { Insulin glargine: Ratio to baseline, } 1.34\end{array}$ & $\begin{array}{l}\text { Exenatide QW: HOMA-S ratio to baseline, } 0.97 \\
\text { Insulin glargine: HOMA-S ratio to baseline, } 1.71\end{array}$ \\
\hline $\begin{array}{l}\text { Russell-Jones D, et al. } \\
2012 \text { (DURATION-4) } \\
{[40]}\end{array}$ & 26-week parallel RCT, monotherapy & $\begin{array}{l}\text { Exenatide QW: Ratio to baseline, } 1.8 \\
\text { Metformin: Ratio to baseline, } 1.4 \\
\text { Pioglitazone: Ratio to baseline, } 1.3 \\
\text { Sitagliptin: Ratio to baseline, } 1.3\end{array}$ & $\begin{array}{l}\text { Exenatide QW: HOMA-S ratio to baseline, } 1.0 \\
\text { Metformin: HOMA-S ratio to baseline, } 1.3 \\
\text { Pioglitazone: HOMA-S ratio to baseline, } 1.5 \\
\text { Sitagliptin: HOMA-S ratio to baseline, } 1.0\end{array}$ \\
\hline \multicolumn{4}{|l|}{ Liraglutide QD } \\
\hline $\begin{array}{l}\text { Marre M, et al. } 2009 \\
(\text { LEAD-1) [43] }\end{array}$ & $\begin{array}{l}\text { 26-week parallel RCT, adjunct to } \\
\text { oral agents }\end{array}$ & $\begin{array}{l}\text { Liraglutide } 0.6 \mathrm{mg} \text { : LS mean difference from } \\
\text { placebo, }+15 \% \\
\text { LS mean difference from rosiglitazone, }+11 \% \\
\text { Liraglutide } 1.2 \mathrm{mg} \text { : LS mean difference from } \\
\text { placebo, }+43 \% \\
\text { LS mean difference from rosiglitazone, }+39 \% \\
\text { Liraglutide } 1.8 \mathrm{mg} \text { : LS mean difference from } \\
\text { placebo, }+34 \% \\
\text { LS mean difference from rosiglitazone, }+30 \%\end{array}$ & $\begin{array}{l}\text { Values not reported; NS differences between } \\
\text { treatments for HOMA-IR }\end{array}$ \\
\hline $\begin{array}{l}\text { Zinman B, et al. } 2009 \\
(\text { LEAD-4) [44] }\end{array}$ & $\begin{array}{l}\text { 26-week parallel RCT, adjunct to } \\
\text { oral agents }\end{array}$ & $\begin{array}{l}\text { Liraglutide } 1.2 \mathrm{mg} \text { : Mean } \pm \text { SE difference from } \\
\text { baseline, }+27 \pm 4.4 \% \\
\text { Liraglutide } 1.8 \mathrm{mg}: \text { Mean } \pm \text { SE difference from } \\
\text { baseline, }+27 \pm 4.2 \% \\
\text { Placebo: Mean } \pm \text { SE difference from baseline, }+6 \\
\pm 4.5 \%\end{array}$ & $\begin{array}{l}\text { Liraglutide } 1.2 \mathrm{mg}: \text { Mean } \pm \text { SE difference from } \\
\text { baseline in HOMA-IR, }-0.6 \pm 0.3 \% \\
\text { Liraglutide } 1.8 \mathrm{mg}: \text { Mean } \pm \mathrm{SE} \text { difference from } \\
\text { baseline in HOMA-IR, }-0.7 \pm 0.3 \% \\
\text { Placebo: Mean } \pm \text { SE difference from baseline in } \\
\text { HOMA-IR, }-0.3 \pm 0.3 \%\end{array}$ \\
\hline $\begin{array}{l}\text { Seino Y, et al. } 2012 \\
\text { (Study A) [45] }\end{array}$ & 24-week parallel RCT, monotherapy & $\begin{array}{l}\text { Liraglutide } 0.9 \mathrm{mg}: \text { Mean difference from } \\
\text { glibenclamide, }+4.2 \%\end{array}$ & Not reported \\
\hline $\begin{array}{l}\text { Seino Y, et al. } 2012 \\
\text { (Study B) [45] }\end{array}$ & $\begin{array}{l}\text { 24-week parallel } \mathrm{RCT} \text {, adjunct to } \\
\text { oral agents }\end{array}$ & $\begin{array}{l}\text { Liraglutide } 0.6 \mathrm{mg} \text { : Mean difference from placebo, } \\
+12.5 \% \\
\text { Liraglutide } 0.9 \mathrm{mg} \text { : Mean difference from placebo, } \\
+20.7 \%\end{array}$ & Not reported \\
\hline
\end{tabular}

*10- $\mu \mathrm{g}$ dose, unless otherwise noted.

†Estimated differences were based on the values at baseline and end point. Exenatide BID mean \pm SD HOMA-B: baseline, 57.8 $\pm 50.1 ;$ Year $1,69.5 \pm 56.2$. Glibenclamide mean \pm SD HOMA-B: baseline, $58.3 \pm 51.6$; Year 1, 56.8 \pm 48.1. Exenatide BID mean \pm SD HOMA-IR: baseline, 7.1 $\pm 2.4 ;$ Year 1, 4.1 \pm 1.1 . Glibenclamide mean \pm SD HOMA-IR: baseline, $7.4 \pm 2.6$; Year $1,6.9 \pm 2.2$

‡Estimated differences were based on the values at baseline and end point. Exenatide BID geometric mean \pm SE HOMA-B: baseline, $51.1 \pm 40.4$; Week $26,56.2 \pm 31.7$. Metformin geometric mean \pm SE HOMA-B: baseline, 47.1 \pm 29.1 ; Week 26, $51.2 \pm 21.1$. Exenatide BID geometric mean \pm SE HOMA-S: baseline, 49.5 \pm 25.6 ; Week 26, $65.3 \pm 30.4$. Metformin geometric mean \pm SE HOMA-S: baseline, $52.1 \pm 21.4$; Week 26, $58.8 \pm 23.6$

BID: twice daily; HOMA-B: homeostatic model assessment of $\beta$-cell function; HOMA-IR: homeostatic model assessment of insulin resistance; HOMA-S: homeostatic model assessment of insulin sensitivity; LS: least-squares; NS: not significant; RCT: randomized controlled trial; QD: once daily; QW: once weekly; SD: standard deviation; SE: standard error.

Table 2: HOMA-B, HOMA-IR, and HOMA-S data from clinical trials of exenatide and liraglutide. 
increased by $42 \%$ with exenatide twice daily plus lifestyle modification $(\mathrm{p}<0.0001)$ and by $23 \%$ with lifestyle modification alone $(\mathrm{p}=0.0015)$. There was no significant difference between treatment groups. Neither treatment had a significant effect on insulin sensitivity.

$\beta$-cell function was investigated using HOMA-B in 112 patients treated for 2 years with exenatide twice daily in a non-controlled extension of three randomized controlled trials [33]. HOMA-B data demonstrated a significant improvement in $\beta$-cell function after 2 years, with a mean relative change of almost $50 \%$ compared with baseline $(\mathrm{p}<0.01)$

Among patients $(\mathrm{N}=128)$ randomized to receive exenatide twice daily or glibenclamide for 1 year, exenatide twice daily significantly improved HOMA-B (Table 2; $\mathrm{p}<0.01$ ), whereas glibenclamide had no significant effect on HOMA-B [34]. HOMA-B was significantly higher with exenatide twice daily compared with glibenclamide $(\mathrm{p}<0.05)$, demonstrating superior improvements with exenatide twice daily. Exenatide twice daily also significantly improved HOMA-IR $(\mathrm{p}<0.01)$.

In a subsequent study, Derosa et al. measured $\beta$-cell function among patients $(\mathrm{N}=171)$ treated with exenatide twice daily or placebo, both in conjunction with metformin [35]. After 1 year, exenatide twice daily significantly increased HOMA-B compared with baseline $(\mathrm{p}<0.01)$ and placebo $(+29 \% ; \mathrm{p}<0.05)$. Furthermore, exenatide twice daily significantly increased first- and second-phase glucose-stimulated $\mathrm{C}$-peptide responses and arginine-stimulated C-peptide responses compared with baseline (all $\mathrm{p}<0.05$ ) and placebo (all $\mathrm{p}<0.05)$. In addition, exenatide twice daily increased the disposition index versus baseline $\left(+102.0 \mathrm{nmol} / 1 \times \mu \mathrm{mol} \mathrm{kg}{ }^{-1} ; \mathrm{p}<0.01\right)$ and placebo $(+67.5 \mathrm{nmol} / \mathrm{l}$ $\left.\times \mu \mathrm{mol} \mathrm{kg}{ }^{-1} ; \mathrm{p}<0.05\right)$. Thus, exenatide twice daily improved multiple measures of $\beta$-cell function.

Preumont et al. undertook a study $(\mathrm{N}=33)$ to determine whether improved glycemic control with exenatide twice daily was related to enhanced $\beta$-cell function and/or insulin sensitivity [36]. After 6 months of exenatide therapy, unadjusted HOMA-B improved significantly $(\mathrm{p}=0.0201)$, while no significant change in HOMA-S was observed (Table 2). Furthermore, exenatide twice daily resulted in a relative increase of $70 \%$ in $\beta$-cell function adjusted for individual insulin sensitivity (HOMA hyperbolic product; $\mathrm{p}=0.0055$ ). The authors concluded that increased $\beta$-cell function played a larger role than insulin sensitivity in improved glycemic control.

\section{Effects of Exenatide Once Weekly on $\beta$-Cell Function}

Clinical studies investigating exenatide once weekly as part of the DURATION-1 (Diabetes Therapy Utilization: Researching Changes in A1C, Weight and Other Factors Through Intervention With Exenatide Once Weekly) program have demonstrated improved $\beta$-cell function. In the DURATION-1 trial $(\mathrm{N}=295)$, improvements in $\beta$-cell function, measured as the ratio of insulin area under the concentration-time curve from 0 to 120 minutes $\left(\mathrm{AUC}_{(0-120 \mathrm{~min})}\right)$ to glucose $\mathrm{AUC}_{(0-120 \mathrm{~min})}$, were greater with exenatide once weekly ( $\Delta$ insulin/ $\Delta$ glucose: $8.8 \mu \mathrm{IU} /$ $\mathrm{mg}$ ) compared with exenatide twice daily ( $\Delta$ insulin/ $\Delta$ glucose: 3.2 $\mu \mathrm{IU} / \mathrm{mg}$ ) after 30 weeks, with a significant improvement from baseline observed for exenatide once weekly [37].

In an open-label extension of the DURATION-1 trial $(\mathrm{N}=194)$, HOMA-B increased after 1 year of treatment with exenatide once weekly $(+39.5 \pm 4.9 \%)$, and improvements were sustained through 3 years $(+25.1 \pm 4.4 \%$; Table 2) [38]. HOMA-B was not measured following treatment discontinuation. These results suggest that improvements in $\beta$-cell health were maintained while patients continued long-term treatment with exenatide once weekly.

In DURATION-3, exenatide once weekly exhibited greater increases in HOMA-B after 26 weeks (ratio to baseline: 1.69) compared with insulin glargine (1.34) [39]. DURATION-4 $(\mathrm{N}=820)$ compared HOMA-B measures with exenatide once weekly versus metformin, pioglitazone, and sitagliptin [40]. After 26 weeks, exenatide once weekly improved $\beta$-cell function to a greater degree versus oral comparators; the endpoint to baseline ratio of HOMA-B was 1.8 with exenatide once weekly versus $1.4,1.3$, and 1.3 with metformin, pioglitazone, and sitagliptin, respectively (all $\mathrm{p}<0.001)$.

\section{Effects of Liraglutide Once Daily on $\beta$-Cell Function}

Liraglutide, a once-daily GLP-1RA, is approved at SC doses of 1.2 $\mathrm{mg}$ and $1.8 \mathrm{mg}$ in the United States and Europe and $0.9 \mathrm{mg}$ in Japan. The effects of liraglutide on $\beta$-cell function have been studied in multiple clinical trials, and effects on HOMA-B specifically are summarized in Table 2 .

Vilsbøll et al. measured $\beta$-cell function in patients $(\mathrm{N}=39)$ randomized to receive liraglutide $0.65,1.25$, or $1.9 \mathrm{mg} /$ day or placebo for 14 weeks [41]. Compared with placebo, liraglutide $1.25 \mathrm{mg}$ and $1.9 \mathrm{mg}$ significantly enhanced first-phase insulin secretion by $118 \%$ and $103 \%$, respectively $(\mathrm{p}=0.02$ and $\mathrm{p}=0.05)$. Only liraglutide 1.25 mg significantly increased second-phase insulin secretion (by 79\%) compared with placebo $(\mathrm{p}=0.005)$. Liraglutide $1.25 \mathrm{mg}$ and $1.9 \mathrm{mg}$ also significantly increased arginine-stimulated insulin secretion (by $114 \%$ and $94 \%$, respectively; $\mathrm{p}=0.02$ and $\mathrm{p}=0.01$ ). Liraglutide had no significant effect on insulin sensitivity or fractional glucose disposal rate. Improvements in first- and second-phase insulin release, as well as arginine-stimulated insulin secretion during hyperglycemia, demonstrate a beneficial effect of liraglutide on $\beta$-cell function.

The randomized controlled LIBRA (Liraglutide and $\beta$-Cell Repair) trial investigated the effects of liraglutide on preservation of $\beta$-cell function in patients $(\mathrm{N}=51)$ with early $\mathrm{T} 2 \mathrm{D}$ (duration of 2.6 years), using the Insulin Secretion-Sensitivity Index-2 (ISSI-2) on oral glucose tolerance test [42]. After 48 weeks, baseline-adjusted ISSI2 was significantly higher with liraglutide versus placebo (339.8 vs. 229.3; $\mathrm{p}=0.008$ ). However, 2 weeks after treatment discontinuation, the benefit with liraglutide was lost (ISSI-2: 191.9 vs. $238.1 ; \mathrm{p}=0.20$ ). The lack of response posttreatment suggests that functional improvements in response to liraglutide exposure did not translate into persistent preservation of $\beta$-cell function.

In the first LEAD (Liraglutide Effect and Action in Diabetes-1) trial, effects on $\beta$-cell function with liraglutide were compared with rosiglitazone or placebo in patients also receiving glimepiride therapy $(\mathrm{N}=1040)$ [43]. Improvements in the proinsulin-to-insulin ratio were significantly greater with liraglutide $1.2 \mathrm{mg}$ and $1.8 \mathrm{mg}$ compared with placebo or rosiglitazone (all $\mathrm{p} \leq 0.02$ ). Additionally, liraglutide 1.2 $\mathrm{mg}$ and $1.8 \mathrm{mg}$ resulted in significant increases in HOMA-B of $39 \%$ and $30 \%$, respectively, compared with rosiglitazone (both $\mathrm{p} \leq 0.05$ ). Liraglutide $1.2 \mathrm{mg}$ significantly increased HOMA-B by a difference of $43 \%$ compared with placebo $(\mathrm{p} \leq 0.05)$. Taken together, these results demonstrate that combination therapy with liraglutide and glimepiride improved $\beta$-cell function to a greater degree than rosiglitazone plus glimepiride or glimepiride alone.

In the LEAD-4 trial $(\mathrm{N}=533)$, liraglutide significantly improved multiple measures of $\beta$-cell function versus placebo [44]. After 26 weeks, liraglutide $1.2 \mathrm{mg}$ and $1.8 \mathrm{mg}$ both significantly improved the 
fasting proinsulin-to-insulin ratio, fasting C-peptide, and HOMA-B compared with placebo (all $\mathrm{p}<0.05$ ). Both doses of liraglutide resulted in an increase in HOMA-B of $27 \%$.

Improvements in $\beta$-cell function-evaluated with the HOMA-B index, proinsulin-to-insulin ratio, and proinsulin-to-C-peptide ratiowere also observed among a Japanese population with T2D $(\mathrm{N}=664)$ included in two 24-week randomized controlled trials [45]. Liraglutide significantly improved HOMA-B versus placebo (liraglutide 0.6 mg: $+12.5 \%, p=0.0470$; liraglutide $0.9 \mathrm{mg}:+20.7 \%, \mathrm{p}=0.0012)$. In addition, liraglutide significantly improved the proinsulin-to-insulin ratio versus glibenclamide (liraglutide $0.9 \mathrm{mg}:-0.81, \mathrm{p}<0.0001$ ) and placebo (liraglutide $0.6 \mathrm{mg}$ : $-0.57, \mathrm{p}=0.0002$; liraglutide $0.9 \mathrm{mg}$ : -0.69 , $\mathrm{p}<0.0001)$. Liraglutide significantly improved the proinsulin-to-Cpeptide ratio versus glibenclamide (liraglutide $0.9 \mathrm{mg}:-1.85, \mathrm{p}<0.0001$ ) and placebo (liraglutide $0.6 \mathrm{mg}$ : $-0.99, \mathrm{p}=0.0016$; liraglutide $0.9 \mathrm{mg}$ : $-1.38, \mathrm{p}<0.0001)$. Thus, liraglutide improved several indicators of $\beta$-cell function compared with either glimepiride or placebo.

A meta-analysis of six large, 26-week, phase 3 liraglutide trials (LEAD-1 through LEAD-6 trials) examined the impact of liraglutide therapy on $\beta$-cell function, using measures of HOMA-B and the proinsulin-to-insulin ratio [46]. Liraglutide $1.2 \mathrm{mg}$ and $1.8 \mathrm{mg}$ improved HOMA-B by a mean change of $31.7 \%$ and $35.7 \%$, respectively. With the exception of glimepiride in combination with metformin (mean change: $+31.8 \%$ ), comparators in the trials improved HOMA-B to a lesser extent (rosiglitazone: $+9.5 \%, \mathrm{p}<0.05$; exenatide twice daily: $+5.7 \%, \mathrm{p}<0.0001$; placebo: $+7.5 \%, \mathrm{p}<0.0001$ ). The mean change in the proinsulin-to-insulin ratio with liraglutide (either dose: -0.08) exceeded changes observed with rosiglitazone $(-0.02)$ and glimepiride $(-0.02)$. Changes in the proinsulin-to-insulin ratio with exenatide and liraglutide were similar. Thus, liraglutide treatment significantly improved markers of $\beta$-cell function in this pooled population.

\section{Effects of Newer GLP-1RAs on $\beta$-Cell Function}

\section{Dulaglutide}

Dulaglutide, a once-weekly GLP-1RA, is available as $0.75-\mathrm{mg}$ and 1.5-mg SC doses. Results for dulaglutide from the AWARD (Assessment of Weekly Administration of LY2189265 [dulaglutide] in Diabetes)-1 trial demonstrated significant improvements in measures of $\beta$-cell function [47]. After 52 weeks, changes from baseline for the updated homeostasis model of $\beta$-cell function (HOMA2-\%B) were significantly greater with dulaglutide $1.5 \mathrm{mg}(+35 \pm 2.6 \%)$ and dulaglutide $0.75 \mathrm{mg}$ $(+26 \pm 2.7 \%)$ versus exenatide twice daily $(+14 \pm 2.8 \%$; both doses, $\mathrm{p}<0.001)$. Neither dulaglutide nor exenatide twice daily conferred benefits on insulin sensitivity, as measured by the updated homeostasis model of insulin sensitivity (HOMA2-\%S). To date, there are no head-to-head clinical trials comparing the effects of dulaglutide and exenatide once weekly on $\beta$-cell function; however, exenatide once weekly resulted in greater improvements in $\beta$-cell function compared with exenatide twice daily [37].

In the AWARD-3 trial, dulaglutide $1.5 \mathrm{mg}$ and $0.75 \mathrm{mg}$ resulted in HOMA2-\%B increases of $30.0 \pm 3.5 \%$ and $22.6 \pm 3.5 \%$, respectively, which were significantly improved compared with metformin $(+9.8$ $\pm 3.5 \% ; \mathrm{p} \leq 0.001$ vs. dulaglutide $1.5 \mathrm{mg}, \mathrm{p}<0.05$ vs. dulaglutide 0.75 $\mathrm{mg}$ ) [48]. Changes in HOMA2-\%S were smaller with dulaglutide $(+5.2 \pm 2.4 \%$ and $+2.7 \pm 2.4 \%$ with dulaglutide $1.5 \mathrm{mg}$ and $0.75 \mathrm{mg}$, respectively) compared with metformin $(+10.8 \pm 2.4 \%)$, consistent with a lesser effect of GLP-1RAs on insulin sensitization.

Results from the AWARD-5 trial $(\mathrm{N}=1098)$ demonstrated significant improvements in $\beta$-cell function with dulaglutide compared with sitagliptin or placebo [49]. After 52 weeks, the change from baseline in HOMA2-\%B significantly improved with dulaglutide 1.5 $\mathrm{mg}(+33.6 \pm 2.5 \%)$ and dulaglutide $0.75 \mathrm{mg}(+22.3 \pm 2.5 \%)$ versus sitagliptin $(+6.7 \pm 2.5 \%$; both doses $\mathrm{p}<0.001)$. Changes in HOMA2$\% \mathrm{~S}$ were similar across treatment groups (dulaglutide $1.5 \mathrm{mg}:+4.7 \pm$ 2.4\%; dulaglutide $0.75 \mathrm{mg}:+2.3 \pm 2.3 \%$; sitagliptin: $+4.3 \pm 2.4 \%)$. In the AWARD-6 trial $(\mathrm{N}=599)$, improvements in HOMA2-\%B were similar with either dulaglutide or liraglutide after 26 weeks of treatment [50].

\section{Lixisenatide}

Lixisenatide, a once-daily GLP-1RA available as $10-\mu \mathrm{g}$ and $20-\mu \mathrm{g}$ SC doses, is approved in Europe for the treatment of T2D in combination with oral glucose-lowering agents and/or basal insulin. Lixisenatide is also available in Australia, Japan, and several countries in Latin America. In a 24-week, randomized, placebo-controlled trial $(\mathrm{N}=680)$, treatment with lixisenatide $20 \mu \mathrm{g}$ once daily (either in the morning or evening) significantly improved $\beta$-cell function compared with placebo [51]. The change from baseline for HOMA-B was $+8.0 \pm 2.45 \%,+4.8 \pm$ $2.49 \%$, and $-4.2 \pm 2.82 \%$ for lixisenatide morning, lixisenatide evening, and combined placebo treatment groups, respectively (lixisenatide morning vs. placebo: $\mathrm{p}=0.0002$; lixisenatide evening vs. placebo: $\mathrm{p}=0.0071)$.

Measures of $\beta$-cell function with albiglutide, a once-weekly GLP$1 \mathrm{RA}$, are not currently reported in the published literature.

\section{Association of $\beta$-Cell Failure With Treatment Outcomes}

A recent prospective study of 546 patients with T2D initiating GLP-1RA therapy analyzed the association between clinical markers of $\beta$-cell failure at baseline and glycemic response (change in $\mathrm{HbAlc}$ ) after 6 months' treatment [52]. All markers of low $\beta$-cell function, including lower fasting $\mathrm{C}$-peptide, lower postmeal urine $\mathrm{C}$-peptide-tocreatinine ratio, positive glutamic acid decarboxylase or islet antigen-2 autoantibodies, longer diabetes duration, and insulin cotreatment, were associated with reduced glycemic response ( $p \leq 0.01$ for all). Thus, consistent with the action of GLP-1RAs to potentiate $\beta$-cell insulin secretion thereby improving glycemic control, patients with low $\beta$-cell function at baseline were less responsive to GLP-1RAs.

\section{Conclusions}

There is a large body of published data from randomized controlled clinical trials, extension studies, and post hoc analyses demonstrating improvements in $\beta$-cell function with GLP-1RA therapies. Exenatide twice daily and liraglutide both improved first- and second-phase insulin secretory responses in patients with T2D. Reductions in the proinsulin-to-insulin ratio further support the beneficial effect of GLP-1RAs on $\beta$-cell function. Numerous studies reported significant improvements in HOMA-B among patients treated with exenatide (twice daily or once weekly), liraglutide, dulaglutide, and lixisenatide, while data on the effects of albiglutide on $\beta$-cell function are not currently available. Long-term treatment with exenatide once weekly demonstrated durable benefits for $\beta$-cell function, with improvements in HOMA-B sustained for up to 3 years on treatment. However, GLP1RA-induced improvements in $\beta$-cell function generally reversed upon treatment discontinuation, suggesting that functional augmentation of $\beta$-cell secretory capacity may not reflect long-term modulation of this system. In contrast to the effects on $\beta$-cell function, treatment with GLP-1RAs had a lesser effect on insulin sensitivity.

Overall, the evidence suggests that GLP-1RAs support $\beta$-cell 
function, thereby improving glycemic control. Additional controlled studies are necessary to investigate whether continued treatment with GLP-1RAs or other glucose-lowering therapies can protect against deterioration of $\beta$-cell function if administered early in the course of T2D.

\section{Acknowledgements}

The development of the manuscript was supported by AstraZeneca. Amanda L. Sheldon, PhD, CMPP, of inScience Communications, Springer Healthcare, provided medical writing support, which was funded by AstraZeneca.

\section{Author Disclosures}

SG, AS, and EH are employees of AstraZeneca.

\section{References}

1. Defronzo RA (2009) Banting Lecture. From the triumvirate to the ominous octet: a new paradigm for the treatment of type 2 diabetes mellitus. Diabetes 58: 773-795

2. American Diabetes Association (2015) (2) Classification and diagnosis of diabetes. Diabetes Care 38 Suppl: S8-8S16.

3. Del Prato S, Tiengo A (2001) The importance of first-phase insulin secretion: implications for the therapy of type 2 diabetes mellitus. Diabetes Metab Res Rev 17: 164-174.

4. Aronoff SL (2004) Glucose metabolism and regulation: beyond insulin and glucagon. Diabetes Spectrum 17: 183-190.

5. Holst JJ, Gromada J (2004) Role of incretin hormones in the regulation of insulin secretion in diabetic and nondiabetic humans. Am J Physiol Endocrinol Metab 287: E199-206.

6. Højberg PV, Vilsbøll T, Rabøl R, Knop FK, Bache M, et al. (2009) Four weeks of near-normalisation of blood glucose improves the insulin response to glucagon-like peptide-1 and glucose-dependent insulinotropic polypeptide in patients with type 2 diabetes. Diabetologia 52: 199-207.

7. Vilsbøll T, Krarup T, Madsbad S, Holst JJ (2002) Defective amplification of the late phase insulin response to glucose by GIP in obese type II diabetic patients. Diabetologia 45: 1111-1119.

8. Aroda VR, Henry RR, Han J, Huang W, DeYoung MB, et al. (2012) Efficacy of GLP-1 receptor agonists and DPP-4 inhibitors: meta-analysis and systematic review. Clin Ther 34: 1247-1258.

9. Flint A, Raben A, Astrup A, Holst JJ (1998) Glucagon-like peptide 1 promotes satiety and suppresses energy intake in humans. J Clin Invest 101: 515-520.

10. Näslund E, Bogefors J, Skogar S, Grybäck P, Jacobsson H, et al. (1999) GLP-1 slows solid gastric emptying and inhibits insulin, glucagon, and PYY release in humans. Am J Physiol 277: R910-916.

11. Nauck MA, Niedereichholz U, Ettler R, Holst JJ, Orskov C, et al. (1997) Glucagon-like peptide 1 inhibition of gastric emptying outweighs its insulinotropic effects in healthy humans. Am J Physiol 273: E981-E988.

12. Nauck MA, Wollschläger D, Werner J, Holst JJ, Orskov C, et al. (1996) Effects of subcutaneous glucagon-like peptide 1 (GLP-1 [7-36 amide]) in patients with NIDDM. Diabetologia 39: 1546-1553.

13. Toft-Nielsen MB, Madsbad S, Holst JJ (1999) Continuous subcutaneous infusion of glucagon-like peptide 1 lowers plasma glucose and reduces appetite in type 2 diabetic patients. Diabetes Care 22: 1137-1143.

14. Bhavsar S, Mudaliar S, Cherrington A (2013) Evolution of exenatide as a diabetes therapeutic. Curr Diabetes Rev 9: 161-193.

15. Larsson H, Holst JJ, Ahren B (1997) Glucagon-like peptide-1 reduces hepatic glucose production indirectly through insulin and glucagon in humans. Acta Physiol Scand 160: 413-422.

16. Baggio LL, Drucker DJ (2007) Biology of incretins: GLP-1 and GIP Gastroenterology 132: 2131-2157.

17. Gedulin BR, Nikoulina SE, Smith PA, Gedulin G, Nielsen LL, et al. (2005) Exenatide (exendin-4) improves insulin sensitivity and \{beta\}-cell mass in insulin-resistant obese fa/fa Zucker rats independent of glycemia and body weight. Endocrinology 146: 2069-2076.

18. Idris I, Patiag D, Gray S, Donnelly R (2002) Exendin-4 increases insulin sensitivity via a PI-3-kinase-dependent mechanism: contrasting effects of GLP 1. Biochem Pharmacol 63: 993-996.

19. Sarkar G, Alattar M, Brown RJ, Quon MJ, Harlan DM, et al. (2014) Exenatide treatment for 6 months improves insulin sensitivity in adults with type 1 diabetes. Diabetes Care 37: 666-670.

20. Cersosimo E, Solis-Herrera C, Trautmann ME, Malloy J, Triplitt CL (2014) Assessment of pancreatic $\beta$-cell function: review of methods and clinical applications. Curr Diabetes Rev 10: 2-42.

21. Wallace TM, Levy JC, Matthews DR (2004) Use and abuse of HOMA modeling Diabetes Care 27: 1487-1495.

22. DeYoung MB, MacConell L, Sarin V, Trautmann M, Herbert P (2011) Encapsulation of exenatide in poly-(D,L-lactide-co-glycolide) microspheres produced an investigational long-acting once-weekly formulation for type 2 diabetes. Diabetes Technol Ther 13: 1145-1154.

23. Fehse F, Trautmann M, Holst JJ, Halseth AE, Nanayakkara N, et al. (2005) Exenatide augments first- and second-phase insulin secretion in response to intravenous glucose in subjects with type 2 diabetes. J Clin Endocrinol Metab 90: 5991-5997.

24. DeFronzo RA, Triplitt C, Qu Y, Lewis MS, Maggs D, et al. (2010) Effects of exenatide plus rosiglitazone on beta-cell function and insulin sensitivity in subjects with type 2 diabetes on metformin. Diabetes Care 33: 951-957.

25. Bunck MC, Diamant M, Cornér A, Eliasson B, Malloy JL, et al. (2009) One-year treatment with exenatide improves beta-cell function, compared with insulin glargine, in metformin-treated type 2 diabetic patients: a randomized, controlled trial. Diabetes Care 32: 762-768.

26. Bunck MC, Cornér A, Eliasson B, Heine RJ, Shaginian RM, et al. (2011) Effects of exenatide on measures of $\beta$-cell function after 3 years in metformin-treated patients with type 2 diabetes. Diabetes Care 34: 2041-2047.

27. Xu W, Bi Y, Sun Z, Li J, Guo L, et al. (2015) Comparison of the effects on glycaemic control and $\beta$-cell function in newly diagnosed type 2 diabetes patients of treatment with exenatide, insulin or pioglitazone: a multicentre randomized parallel-group trial (the CONFIDENCE study). J Intern Med 277 137-150.

28. Ahrén B, Pacini G (2004) Importance of quantifying insulin secretion in relation to insulin sensitivity to accurately assess beta cell function in clinical studies. Eur J Endocrinol 150: 97-104

29. Moretto TJ, Milton DR, Ridge TD, Macconell LA, Okerson T, et al. (2008) Efficacy and tolerability of exenatide monotherapy over 24 weeks in antidiabetic drug-naive patients with type 2 diabetes: a randomized, double-blind, placebocontrolled, parallel-group study. Clin Ther 30: 1448-1460.

30. Yuan GH, Song WL, Huang YY, Guo XH, Gao Y (2012) Efficacy and tolerability of exenatide monotherapy in obese patients with newly diagnosed type 2 diabetes: a randomized, 26 weeks metformin-controlled, parallel-group study. Chin Med J (Engl) 125: 2677-2681.

31. Berg JK, Shenouda SK, Heilmann CR, Gray AL, Holcombe JH (2011) Effects of exenatide twice daily versus sitagliptin on 24-h glucose, glucoregulatory and hormonal measures: a randomized, double-blind, crossover study. Diabetes Obes Metab 13: 982-989.

32. Apovian CM, Bergenstal RM, Cuddihy RM, Qu Y, Lenox S, et al. (2010) Effects of exenatide combined with lifestyle modification in patients with type 2 diabetes. Am J Med 123: 468.

33. Buse JB, Klonoff DC, Nielsen LL, Guan X, Bowlus CL, et al. (2007) Metabolic effects of two years of exenatide treatment on diabetes, obesity, and hepatic biomarkers in patients with type 2 diabetes: an interim analysis of data from the open-label, uncontrolled extension of three double-blind, placebo-controlled trials. Clin Ther 29: 139-153.

34. Derosa G, Maffioli P, Salvadeo SA, Ferrari I, Ragonesi PD, et al. (2010) Exenatide versus glibenclamide in patients with diabetes. Diabetes Technol Ther 12: $233-240$.

35. Derosa G, Franzetti IG, Querci F, Carbone A, Ciccarelli L, et al. (2012) Exenatide plus metformin compared with metformin alone on $\beta$-cell function in patients with type 2 diabetes. Diabet Med 29: 1515-1523.

36. Preumont V, Hermans MP, Brichard S, Buysschaert M (2010) Six-month exenatide improves HOMA hyperbolic product in type 2 diabetic patients mostly by enhancing beta-cell function rather than insulin sensitivity. Diabetes Metab 36: 293-298. 
Citation: Grandy S, Shaunik A, Hardy E (2016) Effects of Glucagon-Like Peptide-1 Receptor Agonists on $\beta$-Cell Function in Patients with Type 2 Diabetes. J Diabetes Metab 7: 643. doi:10.4172/2155-6156.1000643

Page 8 of 8

37. Drucker DJ, Buse JB, Taylor K, Kendall DM, Trautmann M, et al. (2008) Exenatide once weekly versus twice daily for the treatment of type 2 diabetes: a randomised, open-label, non-inferiority study. Lancet 372: 1240-1250.

38. Macconell L, Pencek R, Li Y, Maggs D, Porter L (2013) Exenatide once weekly: sustained improvement in glycemic control and cardiometabolic measures through 3 years. Diabetes Metab Syndr Obes 6: 31-41.

39. Diamant M, Van Gaal L, Stranks S, Northrup J, Cao D, et al. (2010) Once weekly exenatide compared with insulin glargine titrated to target in patients with type 2 diabetes (DURATION-3): an open-label randomised trial. Lance 375: 2234-2243.

40. Russell-Jones D, Cuddihy RM, Hanefeld M, Kumar A, González JG, et al. (2012) Efficacy and safety of exenatide once weekly versus metformin pioglitazone, and sitagliptin used as monotherapy in drug-naive patients with type 2 diabetes (DURATION-4): a 26-week double-blind study. Diabetes Care 35: 252-258.

41. Vilsbøll T, Brock B, Perrild H, Levin K, Lervang HH, et al. (2008) Liraglutide, a once-daily human GLP-1 analogue, improves pancreatic B-cell function and arginine-stimulated insulin secretion during hyperglycaemia in patients with type 2 diabetes mellitus. Diabet Med 25: 152-156.

42. Retnakaran R, Kramer CK, Choi H, Swaminathan B, Zinman B (2014) Liraglutide and the preservation of pancreatic $\beta$-cell function in early type 2 diabetes: the LIBRA trial. Diabetes Care 37: 3270-3278.

43. Marre M, Shaw J, Brändle M, Bebakar WM, Kamaruddin NA, et al. (2009) Liraglutide, a once-daily human GLP-1 analogue, added to a sulphonylurea over 26 weeks produces greater improvements in glycaemic and weight control compared with adding rosiglitazone or placebo in subjects with type 2 diabetes (LEAD-1 SU). Diabet Med 26: 268-278.

44. Zinman B, Gerich J, Buse JB, Lewin A, Schwartz S, et al. (2009) Efficacy and safety of the human glucagon-like peptide-1 analog liraglutide in combination with metformin and thiazolidinedione in patients with type 2 diabetes (LEAD-4 Met+TZD). Diabetes Care 32: 1224-1230.
45. Seino Y, Rasmussen MF, Clauson P, Kaku K (2012) The once-daily human glucagon-like peptide-1 analog, liraglutide, improves $\beta$-cell function in Japanese patients with type 2 diabetes. J Diabetes Investig 3: 388-395.

46. Rigato M, Fadini GP (2014) Comparative effectiveness of liraglutide in the treatment of type 2 diabetes. Diabetes Metab Syndr Obes 7: 107-120.

47. Wysham C, Blevins T, Arakaki R, Colon G, Garcia P, et al. (2014) Efficacy and safety of dulaglutide added onto pioglitazone and metformin versus exenatide in type 2 diabetes in a randomized controlled trial (AWARD-1). Diabetes Care 37: 2159-2167.

48. Umpierrez G, Tofé Povedano S, Pérez Manghi F, Shurzinske L, Pechtner $V$ (2014) Efficacy and safety of dulaglutide monotherapy versus metformin in type 2 diabetes in a randomized controlled trial (AWARD-3). Diabetes Care 37: 2168-2176.

49. Nauck M, Weinstock RS, Umpierrez GE, Guerci B, Skrivanek Z, et al. (2014) Efficacy and safety of dulaglutide versus sitagliptin after 52 weeks in type 2 diabetes in a randomized controlled trial (AWARD-5). Diabetes Care 37: 21492158.

50. Dungan KM, Povedano ST, Forst T, González JG, Atisso C, et al. (2014) Onceweekly dulaglutide versus once-daily liraglutide in metformin-treated patients with type 2 diabetes (AWARD-6): a randomised, open-label, phase 3, noninferiority trial. Lancet 384: 1349-1357.

51. Ahrén B, Leguizamo Dimas A, Miossec P, Saubadu S, Aronson R (2013) Efficacy and safety of lixisenatide once-daily morning or evening injections in type 2 diabetes inadequately controlled on metformin (GetGoal-M). Diabetes Care 36: 2543-2550.

52. Jones AG, McDonald TJ, Shields BM, Hill AV, Hyde CJ, et al. (2016) Markers of $\beta$-cell failure predict poor glycemic response to GLP-1 receptor agonist therapy in type 2 diabetes. Diabetes Care 39: 250-257. 